\title{
On the construction of regional IO tables
}

Citation for published version (APA):

Oude Wansink, M. J., \& Maks, J. A. H. (1997). On the construction of regional IO tables. METEOR, Maastricht University School of Business and Economics. METEOR Research Memorandum No. 043 https://doi.org/10.26481/umamet.1997043

Document status and date:

Published: 01/01/1997

DOI:

10.26481/umamet.1997043

Document Version:

Publisher's PDF, also known as Version of record

\section{Please check the document version of this publication:}

- A submitted manuscript is the version of the article upon submission and before peer-review. There can be important differences between the submitted version and the official published version of record.

People interested in the research are advised to contact the author for the final version of the publication, or visit the DOI to the publisher's website.

- The final author version and the galley proof are versions of the publication after peer review.

- The final published version features the final layout of the paper including the volume, issue and page numbers.

Link to publication

\footnotetext{
General rights rights.

- You may freely distribute the URL identifying the publication in the public portal. please follow below link for the End User Agreement:

www.umlib.nl/taverne-license

Take down policy

If you believe that this document breaches copyright please contact us at:

repository@maastrichtuniversity.nl

providing details and we will investigate your claim.
}

Copyright and moral rights for the publications made accessible in the public portal are retained by the authors and/or other copyright owners and it is a condition of accessing publications that users recognise and abide by the legal requirements associated with these

- Users may download and print one copy of any publication from the public portal for the purpose of private study or research.

- You may not further distribute the material or use it for any profit-making activity or commercial gain

If the publication is distributed under the terms of Article $25 \mathrm{fa}$ of the Dutch Copyright Act, indicated by the "Taverne" license above, 


\title{
On the Construction of Regional IO Tables
}

\author{
M.J. Oude Wansink \\ Maastricht Economic Research Institute on Innovation and Technology \\ University of Maastricht, The Netherlands \\ e-mail: m.oudewansink@algec.unimaas.nl
}

\author{
J.A.H. Maks \\ Department of Economics \\ University of Maastricht, The Netherlands \\ e-mail: h.maks@algec.unimaas.nl \\ paper prepared for the congress of the \\ European Regional Science Association \\ Rome, Italy, August 1997
}

\begin{abstract}
Regional policy makers need regional economical data in order to define and backup their economical policy decisions. Regional input-output (IO) tables have proved to be useful in the policy making process, since the economic effects of policy decisions can be analysed in these models for the region as a whole. Unfortunately, the construction of regional IO tables on the basis of survey methods and other primary data collection methods is very costly and often incomplete. In this paper, we will discuss two techniques which can be applied to derive regional IO tables from national IO tables. In both methods, sectoral production specialization at the regional level is accounted for and affects the interindustrial structure of the region. The IO tables are constructed for 29 industrial sectors and 12 regions in the Netherlands. Policy makers, however, are not interested in the construction of regional IO tables themselves, but more in the economic indicators derived from them. Therefore, we present simple output- and employment-multipliers and employment-transformators derived from the IO tables and discuss some of the differences between them. A description of the economic performance of the Dutch regions is made by looking at the development of the economic indicators over a period of 12 years (1980-1992).
\end{abstract}




\section{Introduction}

Regional policy makers need regional economical data in order to define and backup their economical policy decisions. Regional input-output (IO) tables have proved to be usefull in the policy making process, since the economic effects of policy decisions can be analysed in these models for the region as a whole. Unfortunately, the construction of regional IO tables on the basis of survey methods and other primary data collection methods is very costly and often incomplete. In this paper, we will discuss two techniques which can be applied to derive regional IO tables from national IO tables. In both methods, sectoral production specialization at the regional level is accounted for and affects the interindustrial structure of the region. The IO tables are constructed for 29 industrial sectors and 12 regions in the Netherlands. Policy makers, however, are not interested in the construction of regional IO tables themselves, but more in the economic indicators derived from them. Therefore, we present simple output- and employment-multipliers and employment-transformators derived from the IO tables and discuss some of the differences between them. A description of the economic performance of the Dutch regions is made by looking at the development of the economic indicators over a period of 12 years (1980-1992).

The organization of the paper is as follows. In the second section, we first focus on the terminology that is used throughout this paper. By doing so, we want to avoid any confusion about the precise meaning of the concepts that are dealt with while constructing the regional IO tables. Then, in the third section, we describe the data used for our purposes, since the construction of regional IO tables heavily depend on the availability of national IO- and regional data. In section 4, we start to build up the regional IO table by means of a discussion of the topic of interregional and international trade. Section 5 then discusses the first technique for deriving the intermediary transactions block of the IO table, which was introduced by Klaassen and Verster (1974). Section 6 concentrates on our own method for obtaining the regional intermediary transactions. While constructing the regional IO tables throughout the sections 4 to 6 , we present some examples for the Netherlands in these sections. This makes a more elaborate discussion of the regional IO tables themselves abundant, which means that we can concentrate on simple output-multipliers in section 7. Section 8 and 9 will discuss employment-multipliers and -transformators, respectively. Section 10 summarizes and concludes.

\section{Terminology}


Table 1 shows the main framework that will be dealt with in this paper. The IO table is a complete description of the economic transactions of a region. We will not discuss the organization of the input-output tables here, because good descriptions can be found in the literature (see e.g. Miller and Blair (1985)). For this moment, a short explanation of the terminology and the variables used here must do. Subscripts $i$ and $j$ are used as sectoral indices for the rows and the columns in the IO table, respectively.

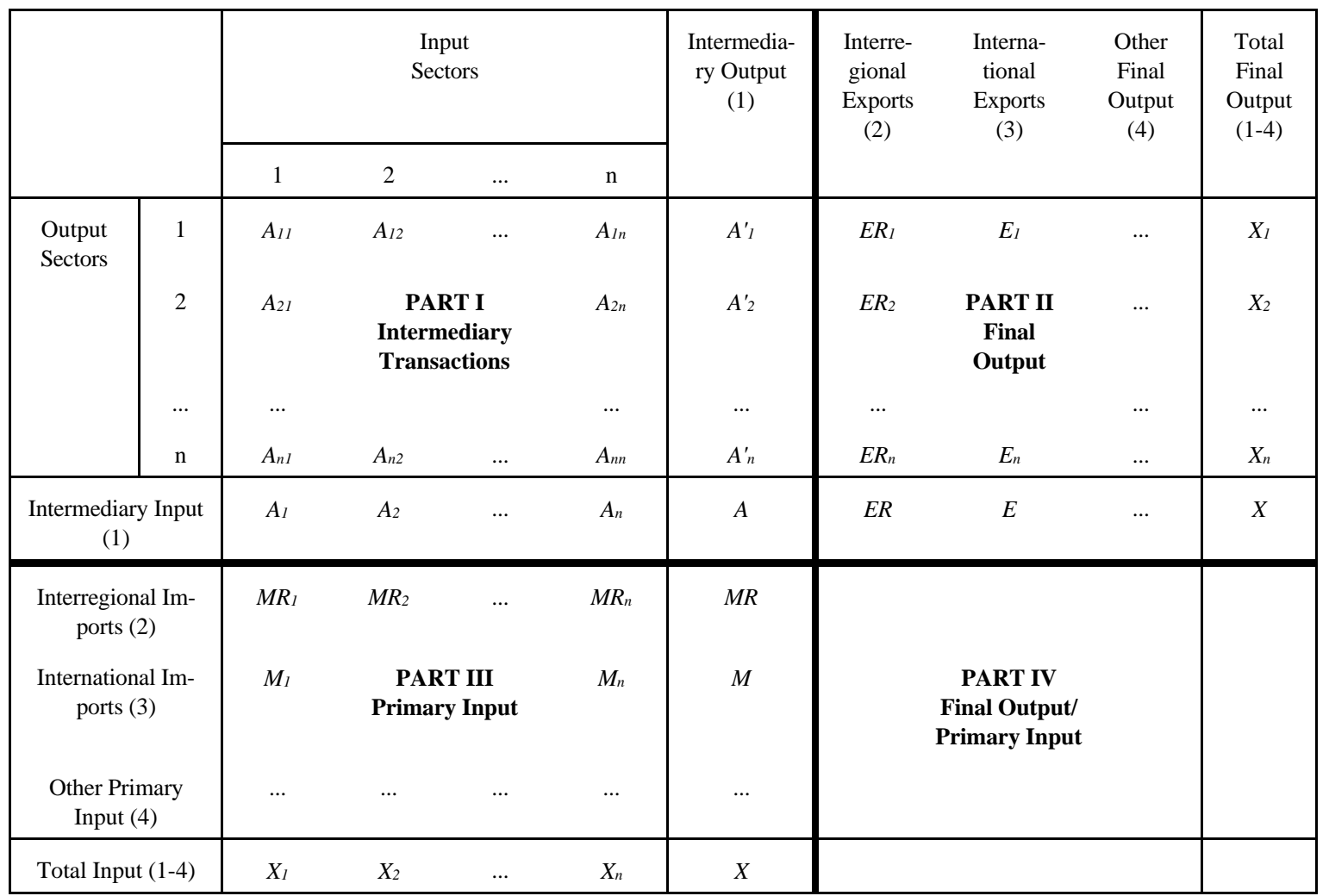

Table 1

Input-Output Transactions Table

The total intermediary output of a sector is described by $A_{i}^{\prime}$, whereas the total intermediary input of a sectors is given by $A_{j}$. It is true that

Install Equation Editor and doubleclick here to view equation. 
and

Install Equation Editor and double-

click here to view equation.

where $n$ is the total number of sectors distinguished. The row (output) of a business sector is completed with interregional exports $E R_{i}$, international exports $E_{i}$, the usual final demand categories and total output $X_{i}$. Those output categories are described in part II of Table 1. The column (input) of a business sector is completed with interregional imports $M R_{j}$, international imports $M_{j}$, the usual primary cost categories and total input $X_{j}$. Those input categories are described in part III of Table 1. Finally, we distinguish economic transactions which are both counted for as final demand and a primary cost in part IV of Table 1.

Intermediary transactions refer to transactions between sectors within a region (or, in case of the national IO table, within a country). Part I of Table 1 describes the intermediary transactions $A_{i j}$ between output sectors $i$ (rows) and input sectors $j$ (columns). Interregional exports and imports refer to trade between sectors in different regions, but within a country. In the construction of regional IO tables, we will not specify the exact destination of the intermediary output or the exact source of the intermediary input since we lack any information about them. International exports and imports refer to trade with other countries. Both the primary cost and final demand categories refer to the region itself (or, in case of the national IO table, to the country itself). The final demand categories distinguished here are: household consumption $(C h)$, government consumption $(C g)$, gross investment (including public investment) $(I)$, and mutations in inventories $(T)$. The primary cost categories distinguished here are: depreciation $(D)$, indirect taxes minus sector-specific subsidies

(TS ), wages and salaries (W), social contributions of employers (SC), and other income

$(O I)$. In this paper, we sometimes speak of input- or technical coefficients. By this, we mean the different input categories divided by total output. Thus, for every sector we have 36 input- or technical coefficients (29 intermediary transactions with other sectors, 2 types of imports and 5 primary cost transactions). Part of the data necessary for the construction of an IO table is available at the regional level. Because still some regional information is lacking, we will use the available regional information in combination with the national IO table to construct the regional IO table. In the following section, we will discuss the availability of data. 


\section{The Data}

We use 3 different data sources for the construction of the Dutch regional IO table. First, we make use of the Dutch national IO table, which is yearly published by the CBS, the Dutch Central Bureau of Statistics (National Accounts). Because the publication of national IO tables is lagging some years behind, we have them only available up to 1992. For our purposes, we will use the national IO tables of 1980, 1985, 1990 and 1992 expressed in current prices. Although we would prefer to use IO tables in constant prices, we have regional data available which is given in current prices only (for a description, see below). As a consequence, we use the national IO tables given in current prices, thereby making the assumption that both output and input prices at the regional level can be approximated by the prices at the national level. We must stress that the regional IO tables constructed in this paper are still expressed in terms of current prices.

The second data source, the regional dataset, is yearly published by the CBS (Regionaal Economische Jaarcijfers) and lags some years behind too. Although data is available for approximately 40 seperate regions in the Netherlands, we prefered to IO tables for only 12 regions. Regional policy is defined at the level of the 12 so called 'provinces' of the Netherlands, which explains our choice for restricting the analysis to these 12 regions. In Figure 1 (next page), we have depicted a map of the Netherlands, divided by the 12 regions. For the part of the Netherlands that has been gained from the sea, Flevoland, we have only data available for 1992. For the other regions, we use data for 1980, 1985, 1990 and 1992.

The regional data distinguishes between 38 business sectors which, however, are not producing in every region. Therefore, a sectoral classification has been made which required every sector to produce in every region. This leaves us with 29 sectors: one agricultural, 13 industrial and 15 services sectors. For a description of the sectoral classification, see Annex 1. For every sector in a region, we have the following data available: total output, total input (i.e. output minus value added), value added, indirect taxes minus sector-specific subsidies, wages and salaries, social contributions of employers, other income (including depreciation), international exports, and employment (full time employees). We completed the regional dataset by adjusting the employment figures in order to account for self-employment too. We simply multiplied employment by the (total employment/employees) ratio which is known for every sector at the national level (Central 
Planning Bureau, Lange Termijn Reeksen).

Fout! Bladwijzer niet gedefinieerd. 


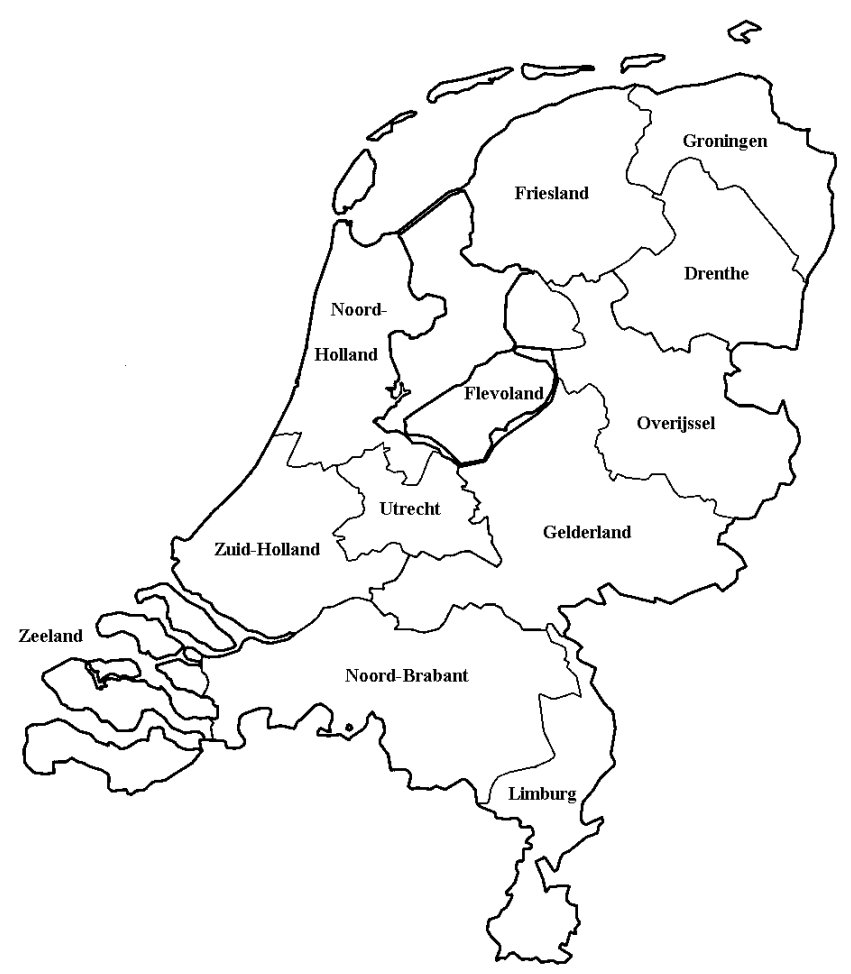

Figure 1

Regional Structure of the Netherlands

\section{ContainsDatafor}

\section{PostscriptOnly.}

Figure 2

Regional Share in Output, Income and Employment 
Some main regional characteristics of the Netherlands are given in Figure 2 (previous page), i.e. the regional shares in national output, income and employment. ${ }^{1}$ Zuid-Holland is the economically largest region in the Netherlands, accounting for more than almost 25 percent of national output, income and employment. Together with Noord-Holland, the second largest region, these shares increase to approximately 40 percent. As could be expected, Flevoland is the economically smallest region of the Netherlands.

The third data source concerns interregional and transport figures for the Netherlands. Those figures are also yearly published by the CBS (Statistiek van het binnenlands goederenvervoer) and will be used to compute interregional and international trade flows at the regional level. We have no data available for 1980. The next section will concentrate on regional trade.

\section{Regional Trade}

In the regional dataset provided by the CBS, we have only regional exports to other countries available. However, it is clear from the IO table presented in section 2 that we need information about 3 other types of regional trade: interregional exports, interregional imports and international imports. In this section, we will describe our computations of regional trade. The strategy to obtain 
the missing trade flows is as follows. First we will compute the international and interregional imports, since we have far more information in our regional database about sectoral inputs than output. This not only facilitates the computation of imports, but also make the results more reliable. Once interregional imports have been obtained, we will compute the interregional exports.

The starting point of our computational efforts is the assumption that the share of international imports in net input (i.e. total output minus value added) in every sector is the same in all regions. Thus

Install Equation Editor and doubleclick here to view equation.

Note that the regional, sectoral net input $A+M+M R$ can easily be obtained from the data of the CBS, whereas output categories are not available in the regional dataset. This illustrates why we start by defining the input categories first.

Once we computed the international imports per sector for all regions, we also have the total of intermediary transactions and interregional imports, $A+M R$, for all sectors in all regions.

In order to distinguish between them, we have made use of the CBS transport data described in the previous section. From the CBS, we have information available about the Dutch regional structure of transported goods (expressed in kilograms). In Table 2, we present a transport matrix for the Netherlands for $1992{ }^{2}$

\begin{tabular}{|l|rrrr|}
\hline \multirow{2}{*}{ Transported Goods From: } & \multicolumn{4}{|c|}{$\begin{array}{c}\text { Transported Goods To: } \\
\text { (mln kilograms) }\end{array}$} \\
\cline { 2 - 5 } North & North & East & West & South \\
\cline { 2 - 5 } East & 41285 & 5934 & 7271 & 1478 \\
West & 8973 & 61101 & 18564 & 7156 \\
South & 7070 & 19917 & 158590 & 25690 \\
\hline
\end{tabular}

Table 2

Transport Goods Matrix

The Netherlands, 1992, 4 Regions

(Source: CBS, Statistiek van het binnenlands goederenvervoer 1992, Tabel 2. 
It is clear from Table 2, that intraregional transport (transport within regions) has a higher share (60-70\%) in total transport than interregional transport (transport accross regions). In other words: we expect the level of intermediary transactions to be higher than the level of interregional imports. We considered the "Transported Goods To"-column, with the exclusion of the transported goods to the region itself, as an approximation of interregional imports, whereas intraregional transport can be considered as an approximation of intermediary transactions. From Table 2, we can then calculate the [interregional imports/intermediary transactions] ratio, which will be below 1 . For 1992, this ratio is 0.46 for the North, 0.57 for the East, 0.29 for the West and 0.42 for the South. With these ratios, which are available for 1985, 1990 and 1992 and can be extrapolated for 1980, we can split the interregional imports from the $A+M R$ total and isolate intermediary transactions Install Equation Editor and double-

where $R_{m}{ }^{r}$ is the abovementioned ratio for the region, which is the same for all regions (12-regions classification) in the 4-region classification and for all sectors.

We are aware of the drawbacks of this methodology. First, there is no differentiation between the regions of our classification which sum up to the regions of the 4-regions classification. Second, we cannot distinguish between [interregional imports/intermediary transactions] ratios of different sectors. Third, the observed interregional trade figures only concern the transport of goods, which may not be a good indicator for regional trade in services. And finally, we are aware of double counts when the distribution of (intermediary) goods takes place via intermediates, such as wholesale trade companies. Unfortuntaly, we don't have alternative sources to derive the magnitude of interregional trade flows, and it may be clear by now that the disadvantages of our methodology call for more specific interregional trade statistics.

Now that we have derived interregional imports for all regions, we will compute interregional exports. In the next two sections, we will discuss two methods for deriving the intermediary transactions. Once we obtained intermediary input, we also obtained intermediary output. From Table 2, we can derive the [interregional exports/intermediary transactions] ratio in the same way as we did for the [interregional imports/intermediary transactions] ratio. In this case, we considered the "Transported Goods From"-column, with the exlusion of the transported goods from the region itself, as an approximation of interregional exports. Therefore, we can compute the interregional exports. However, by definition, the sum of all interregional imports must equal the sum of interregional exports. Thus, we rescale the interregional exports to the sum of all regional 
imports. So, first we have

Install Equation Editor and double-

click here to view equation.

where $R_{x}^{r}$ is the abovementioned [interregional exports/intermediary transactions] ratio. Then, we rescale the interregional exports to the total of interregional imports

(6)

Install Equation Editor and double-

click here to view equation.

In Table 3 (next page), we present the 1992 interregional, international and total trade flows for the 12 Dutch regions, expressed as shares of total input (imports) or output (exports). The first remark with respect to Table 3 concerns the impact of the 4-regions classification (see footnote 2 ) on the outcomes for interregional trade flows per region. We have put the higher value of either imports or exports (interregionally, internationally and totally) in a bold lettertype, and it is obvious that all the "West"-regions (Noord-Holland, Zuid-Holland, Utrecht and Zeeland) are net-exporters when it comes to interregional trade.

All other regions are net-importers. In addition, we don't find very much variation in the interregional imports shares among the "West"-regions, but we should stress the point that this is merely a coincidence. The logic of this point lies in the definitions of regional trade flows presented in this section.

\begin{tabular}{|l|rr|rr|rr|}
\hline & \multicolumn{2}{|c|}{$\begin{array}{r}\text { Interregional Trade } \\
\text { (\% of total output) }\end{array}$} & \multicolumn{2}{|c|}{$\begin{array}{r}\text { International Trade } \\
\text { (\% of total output) }\end{array}$} & \multicolumn{2}{|c|}{$\begin{array}{r}\text { Total Trade } \\
\text { (\% of total output) }\end{array}$} \\
& $\begin{array}{r}\text { Imports } \\
\text { (1) }\end{array}$ & $\begin{array}{r}\text { Exports } \\
(2)\end{array}$ & $\begin{array}{r}\text { Imports } \\
(3)\end{array}$ & $\begin{array}{r}\text { Exports } \\
(4)\end{array}$ & $\begin{array}{r}\text { Imports } \\
(5)\end{array}$ & $\begin{array}{r}\text { Exports } \\
(6)\end{array}$ \\
\hline Groningen & $\mathbf{8 . 4}$ & 6.6 & 14.1 & $\mathbf{2 4 . 2}$ & 22.5 & $\mathbf{3 0 . 8}$ \\
Friesland & $\mathbf{1 0 . 6}$ & 8.3 & 14.0 & $\mathbf{1 7 . 9}$ & 24.6 & $\mathbf{2 6 . 2}$ \\
Drenthe & $\mathbf{1 0 . 0}$ & 7.8 & 14.4 & $\mathbf{2 1 . 0}$ & 24.4 & $\mathbf{2 8 . 8}$ \\
Overijssel & $\mathbf{1 2 . 3}$ & 12.2 & 16.3 & $\mathbf{2 0 . 5}$ & 28.5 & $\mathbf{3 2 . 7}$ \\
Flevoland & $\mathbf{1 2 . 0}$ & 11.9 & 10.6 & $\mathbf{1 6 . 9}$ & 22.6 & $\mathbf{2 8 . 8}$ \\
Noord-Holland & 7.5 & $\mathbf{8 . 2}$ & 13.2 & $\mathbf{1 9 . 3}$ & 20.6 & $\mathbf{2 7 . 5}$ \\
Zuid-Holland & 7.4 & $\mathbf{8 . 1}$ & 16.0 & $\mathbf{2 3 . 0}$ & 23.4 & $\mathbf{3 1 . 1}$ \\
Utrecht & 7.5 & $\mathbf{8 . 2}$ & 11.9 & $\mathbf{1 3 . 2}$ & 19.4 & $\mathbf{2 1 . 4}$ \\
Gelderland & $\mathbf{1 2 . 9}$ & 12.8 & 15.0 & $\mathbf{1 8 . 7}$ & 27.9 & $\mathbf{3 1 . 5}$ \\
Noord-Brabant & $\mathbf{1 0 . 0}$ & 9.5 & 16.3 & $\mathbf{2 3 . 2}$ & 26.3 & $\mathbf{3 2 . 7}$ \\
Zeeland & 7.8 & $\mathbf{8 . 2}$ & 20.7 & $\mathbf{3 1 . 4}$ & 28.3 & $\mathbf{3 9 . 6}$ \\
Limburg & $\mathbf{9 . 8}$ & 9.3 & 17.2 & $\mathbf{2 5 . 0}$ & 27.0 & $\mathbf{3 4 . 3}$ \\
\hline
\end{tabular}




\section{Table 3}

Regional Trade

The Netherlands, 1992, 12 Regions

Furthermore, differences between interregional imports and interregional exports show little variation among regions within the 4 areas (North, East, West and South). In fact, this variation is due to the methodology used and is one of the drawbacks of the lack of interregional trade data.

What can we conclude from Table 3? First, the two largest economic regions are net exporters (interregionally). The main part of their imports comes from abroad (about two thirds), which is lower for other regions (compare, for instance, with Flevoland (47\%) and Gelderland (54\%)). Second, among the "North"-regions (Groningen, Friesland and Drenthe), some variation between the relative level of interregional imports can be observed. Groningen seems to be an interregionally much "closer" economy than Friesland or Drenthe.

Finally, the "West"-regions (Noord-Holland, Zuid-Holland, Utrecht and Zeeland) import a lower share of their total input from other regions than the other regions. On the other hand, on average, they have the same relative interregional exports.

With respect to international trade, it is striking to note that all regions are net exporters. The shares of international exports vary from 13\% (Utrecht, which seems logic from a geographical point of view) to $31 \%$ (Zeeland), whereas relative international imports range from $11 \%$ (Flevoland) to $21 \%$ (again Zeeland). With respect to international trade, we consider Utrecht and Flevoland as the most "closed" economies, whereas Zeeland seems to be the most "open" economy. This conclusion is more or less confirmed when we look at total trade flows. Finally, we stress the point that variation among regions in the case of total trade flows (columns (5) and (6) in Table 3) is less than in the case of interregional trade flows (columns (1) and (2)) or international trade flows (columns (3) and (4)). Probably, some regions focus more on international trade (Zeeland, Zuid-Holland), whereas others concentrate more on interregional trade (Flevoland, Gelderland).

Although we have the sectoral sum of intermediary transactions available now for every region, we still have to divide them sectorally. In the next sections, we will describe the two methods applied in order to compute the intermediary transactions (part I of the IO table presented in section 2). 


\section{Intermediary Transactions: Cross-Sectoral Location Quotients (Method 1)}

We construct regional IO tables which are derived from the national IO table. However, regional input coefficients differ from the national ones because of two reasons. First, regional production structures differ because of differences between the (average) production technology used. Technological differences may be caused by differences in infrastructure, the availability of (skilled) labour or other regional characteristics. Second, the structure of intersectoral (intermediary) transactions will regionally be different because of regional specialization. For example, some regions are specialized in the production of manufacturing or services goods, whereas others are specialized in agricultural production. When we derive the regional IO tables from the national one, we should account for these technological and specialization differences.

First, we adjust the national input coefficients for regional technological differences by rescaling them to the regional/national ratio of output minus the value added and the regional imports, both interregional and international. We are aware of the fact that such an adjustment will not take into account all regional differences in technology, but we have no other information available. The sectoral intermediary input at the regional level has now been either down- or upscaled with respect to the sectoral intermediary input at the national level.

With respect to regional specialization differences, we compare two different methods for adjusting the national input coefficients in order to obtain the regional ones. In this section, we discuss the cross-sectoral location quotient method proposed by Klaassen and Verster (1974), whereas in the next section, we will propose another adjustment procedure. The major reason for proposing a second computational method is that the cross-sectoral location quotient is only capable of adjusting intermediary transactions for sectors which are relatively underspecialized in a region, which will be made clear below. Therefore, adjustment for sectoral specialization in regions in this method is asymmetric, whereas our method allows us to account also for overspecialization. In order to derive an approximation of sectoral specialization at the regional level, Klaassen and Verster (1974) propose the cross-sectoral location quotient $L_{i j}^{\prime}$, which is defined as ${ }^{3}$

Install Equation Editor and doubleclick here to view equation.

It is clear from (7) that if $L_{i j}^{\prime}>1$, production in sector $i$ is, relative to production in sector $j$, higher 
at the regional than at the national level. Therefore, this region is said to be specialized in the production of sector $i$ relative to sector $j . L_{i j}^{\prime}$ can take values from zero to infinity. This causes a problem, because by applying location quotients which are far above one, sectoral production could be 'blown up'. Therefore, Klaassen and Verster (1974) suggest to truncate the location quotients with a value higher than one

Install Equation Editor and doubleclick here to view equation.

Next, the intermediary transactions between sectors at the regional level can be derived from the national intermediary transactions in the following way

Install Equation Editor and double-

click here to view equation.

Note, that the proposed adjustment of national intermediary input coefficients by the cross-sectoral location quotients in (9) actually leads to an underestimation of the total regional intermediary input because of the asymmetric treatment of these quotients described in (8). In other words, when regional value added would relatively be the same as national value added in every sector, this method excludes the possibility of regional intermediary input coefficients to be higher than the national ones. To solve for this problem, we rescale the obtained intermediary input coefficients to the total intermediary transactions obtained in the previous section

Install Equation Editor and doubleclick here to view equation.

Even after the rescaling of intermediary transactions in (10), the results are biased because of the asymmetric truncation of location quotients in (8). In the next section, we will therefore propose a more symmetric adjustment procedure in order to avoid this bias.

\section{Intermediary Transactions: Symmetric Adjustment (Method 2)}

We propose another methodology for calculating regional intermediary transactions in order to avoid the bias described in the previous section. Instead of applying the truncated cross-sectoral location quotient (equation (8)), we propose a symmetric adjustment of intermediary transactions. For this purpose, we first define a sectoral location quotient, which is the simple version of the quotient defined in equation (7) in the previous section 
It is the (regional output share/national output share) ratio of only one sector. This quotient can take values from 0 to infinity. In the former case, the regional output share of the sector is 0 (regional underspecialization), whereas in the latter case the regional output share of the sector is relatively high (regional overspecialization). In the previous section, regional underspecialization was taken into account in the adjustment of intermediary transactions, but regional overspecialization could not be taken into account because of the infinity-problem. Therefore, we have to set an upper limit for the adjustment of intermediary transactions. We assume that regional input coefficients of intermediary transactions cannot be higher than double the national coefficients.

Thus, our upper limit is 2 and we develop the following symmetric adjustment (SA) index

The index has the following properties:

- if $x$ equals 0 , then $S A$ equals 0 ;

- if $x$ equals 1 , then $S A$ equals 1 ;

- if $x$ approaches infinity, then $S A$ approaches 2 .

We adjust the input coefficients by taking into account the $S A$ index of the output sector. Total intermediary input has already been defined in section 4, so that no adjustment for regional specialization have to be made with respect to the input sector. This adjustment takes place by rescaling the total of the computed intermediary transactions to the known total of intermediary transactions, as described in equation (10). The regional intermediary transactions are now calculated in the following way

\section{Install Equation Editor and double-}

click here to view equation.

Equation (12) replaces the equations (7) and (8) of the previous section, whereas equation (13) replaces equation (9). As mentioned before, rescaling of the intermediary input defined in (13) to the actual intermediary input obtained in the previous section is described by equation (10).

A comparison between the two methods is complicated because of the rescaling. On the one hand, the location quotient method underestimates the input coefficients of the relative larger 
sectors within a regions. One the other hand, by definition, rescaling the sum of the computed input coefficients to an already fixed (intermediary transactions/total input) ratio increases all input coefficients in this method. Looking at Table 4 (next page), we find mixed results. In this table, we present the 1992 intermediary input for the "Extraction of Minerals and Chemical Industry"-sector in Zuid-Holland, the largest sector (in terms of regional output) in the largest region. The characteristics of this sector ensure that cross-sectoral location quotients are below 1 for almost all output sectors. In the table, we also present sectoral shares in total output for the Netherlands as a whole and for Zuid-Holland (first and second column, respectively). It is possible to compute the cross-sectoral location quotients and the symmetric adjustment index for every sector from Table 4.

The rescaling effect is most obvious from the largest input, i.e. the input from the sector itself (sector 2).

The intermediary input from the sector itself is $10 \%$ higher in the case of method 1 . Note that both the cross-sectoral location quotient and the symmetric adjustment index of the own sector equal 1 , which means that in this case the differences between the outcomes of both methods can only be explained by the rescaling.

\begin{tabular}{|c|c|c|c|c|}
\hline \multirow[b]{2}{*}{ Output Sector } & \multicolumn{2}{|c|}{$\begin{array}{c}\text { Output Share } \\
\text { (\% of total output) }\end{array}$} & \multicolumn{2}{|c|}{$\begin{array}{c}\text { Intermediary } \\
\text { Transactions } \\
\text { (mln Hfl) }\end{array}$} \\
\hline & National & Regional & $\begin{array}{c}\text { Method } \\
1\end{array}$ & $\begin{array}{l}\text { Method } \\
2\end{array}$ \\
\hline 1. Agriculture, forestry and fishing & 4.2 & 3.3 & 14.8 & 19.7 \\
\hline 2. Extraction of minerals and chemical industry & 9.3 & 15.1 & 5098.1 & 4615.5 \\
\hline 3. Food, drink and tobacco industry & 8.0 & 5.4 & 54.9 & 77.6 \\
\hline 4. Textile industry & 0.6 & 0.1 & 0.6 & 1.3 \\
\hline $\begin{array}{l}\text { 5. Leather, leather goods, footwear and clothing } \\
\text { industry }\end{array}$ & 0.3 & 0.1 & 2.3 & 4.3 \\
\hline 6. Timber and wooden furniture industry & 0.8 & 0.5 & 18.3 & 25.5 \\
\hline 7. Manufacturing of paper and paper products & 0.9 & 0.2 & 29.7 & 56.0 \\
\hline 8. Printing and publishing & 2.0 & 1.6 & 68.8 & 90.5 \\
\hline 9. Manufacturing of products for construction & 0.9 & 0.7 & 21.1 & 28.4 \\
\hline 10. Production and preliminary processing of metals & 0.6 & 0.4 & 15.8 & 23.4 \\
\hline 11. Metal products and machinery & 4.5 & 3.1 & 153.2 & 213.4 \\
\hline 12. Electrical industry & 2.4 & 1.5 & 28.7 & 41.1 \\
\hline 13. Manufacturing of transport products & 2.0 & 1.8 & 7.7 & 9.5 \\
\hline 14. Other industries & 0.5 & 0.4 & 14.9 & 19.1 \\
\hline 15. Energy and water & 2.4 & 2.2 & 283.3 & 344.0 \\
\hline 16. Construction & 7.8 & 7.8 & 117.2 & 138.9 \\
\hline 17. Wholesale and retail distribution & 10.3 & 10.4 & 130.7 & 153.6 \\
\hline 18. Hotels and catering & 2.0 & 1.7 & 50.8 & 64.6 \\
\hline
\end{tabular}




\begin{tabular}{|l|rr|rr|} 
19. Repair of consumer goods and vehicles & 1.3 & 1.3 & $\mathbf{1 9 . 9}$ & 23.8 \\
20. Transport & $\mathbf{4 . 7}$ & 6.6 & 189.2 & $\mathbf{1 8 4 . 7}$ \\
21. Communication & $\mathbf{1 . 5}$ & 1.7 & $\mathbf{9 2 . 1}$ & 101.4 \\
22. Banking and finance & 2.6 & $\mathbf{2 . 0}$ & $\mathbf{9 . 3}$ & 12.5 \\
23. Insurance & $\mathbf{1 . 6}$ & 2.2 & $\mathbf{1 5 . 6}$ & 15.8 \\
24. Letting of real estate by the owner & 5.6 & $\mathbf{5 . 2}$ & $\mathbf{6 6 . 3}$ & 80.9 \\
25. Business services and renting & $\mathbf{6 . 0}$ & 7.0 & $\mathbf{1 0 7 6 . 3}$ & 1178.0 \\
26. Medical, health and veterinary services & 3.8 & $\mathbf{3 . 6}$ & $\mathbf{0 . 2}$ & 0.3 \\
27. Culture, sport and recreation & 1.4 & $\mathbf{1 . 2}$ & $\mathbf{8 . 5}$ & 10.8 \\
28. Other services & $\mathbf{3 . 5}$ & 3.7 & $\mathbf{9 0 . 3}$ & 104.3 \\
29. Public services & $\mathbf{8 . 6}$ & 9.0 & $\mathbf{2 6 2 . 3}$ & 302.1 \\
\hline
\end{tabular}

Table 4

Intermediary Transactions Comparison

Zuid-Holland, 1992, Input Sector 2

(Extraction of Minerals and Chemical Industry)

Large absolute differences between the results of method 1 and 2 can be found in the sectors 11 ("Metal products and machinery", Hfl -60 mln), 15 ("Energy and water", Hfl -61 mln) and 25 ("Business services and renting", Hfl $-102 \mathrm{mln}$ ). Large relative differences can be found in the sectors 4 ("Textile industry", -53\%), 5 ("Leather, etcetera", -47\%) and 7 ("Manufacturing of paper and paper products", -47\%). In all these cases, the intermediary transactions computed with method 1 have lower values than those computed with method 2. Table 4 shows that this is true for all sectors with the exception of the own sector's input and the input from sector 20 ("Transport"). Apart from sector 2 itself, the relative difference between the regional and the national output share is the highest of all sectors with a higher regional than national output share. This certainly accounts for the result for the transport sector.

Now that we have calculated the intermediary transactions, as well as the international and interregional imports for every sector and every region, we will complete the definition of the regional IO-table in the next section.

\section{Simple Output-Multipliers}

Throughout the sections 4 through 7, we have derived a complete system of regional IO tables which makes it possible to evaluate the underlying economic structure of the distinguished regions. The input-output framework is very suitable for the derivation of multipliers, which measure direct and indirect economic effects of specific policy actions. In this section, we will focus on the 
development of the simple output multiplier (see e.g. Miller and Blair (1985), p. 103). In order to derive this multiplier, we decompose a sector's output $(X)$ into intermediary output $(A)$ to other sectors and final demand $(F)$. This compares with our definition of part I and part II of the IO table described by Table 1. Next, a linear relationship between intermediary output and total output is assumed, which leads to the following definition of a sector's output

Install Equation Editor and doubleclick here to view equation.

where $a=A / X$. Furthermore, $A$ is a $n x n$ matrix of intermediary transactions between $n$ sectors, $X$ is a $1 x n$ vector describing the total output of these sectors and $F$ is a $f x n$ matrix describing the output of these sectors because of final demand (where $f$ final demand categories are distinguished here).

From (20) it follows that

where $I$ is the $n x n$ identity matrix. The $(I-a)^{-1}$ matrix is known as the Leontief inverse matrix (LIM). When we indicate the LIM elements with $a_{i j}$, then it is easy to show that any change in the final demand for sector $j$ 's output, $\Delta F_{j}$, will lead to the following change in total regional production

This is the simple output multiplier, which is defined as the change in total output due to a change in final demand. The change in total output consists of a direct effect, i.e. the initial changed final demand, and an indirect effect, i.e. the creation of extra production via the intermediary transactions with other sectors. Additional final demand require additional inputs.

For a more detailed elaboration of multipliers, we refer to Miller and Blair (1985). For our purposes, it is sufficient to mention that simple output multipliers can be used for regional economic policy purposes (public investment programs). A changes in regional production leads to a change in regional income, affecting the regional level of welfare (measured by per capita income).

We will first concentrate on the differences between national and regional multipliers. In Table 5 (next page), we present the 1992 simple output multipliers of the 29 sectors for the Netherlands, Zuid-Holland and Flevoland. ${ }^{4}$ Zuid-Holland is economically the largest region in the Netherlands, whereas Flevoland is the smallest. Two conclusions can immediately be drawn from the table. First, in general, national output multipliers are larger than regional ones. At the national level, only international imports form a leakage in production, whereas at the regional level, also 
interregional imports play a role. Therefore, national output multipliers are expected to be higher than regional ones. Second, in general, output multipliers in larger regions are higher than in smaller regions. The structure of intermediary transactions in larger regions is more differentiated (in terms of sectoral inputs) than in smaller regions (which are relatively more specialized). This must be the reason for the differences between output multipliers of Zuid-Holland and Flevoland in Table 5. There are two exceptions on the abovementioned two general conclusions. First, the output multiplier of the electrical industry (sector 12) in Zuid-Holland (1.26) is higher than the one for the Netherlands (1.24) as a whole.

\begin{tabular}{|c|c|c|c|}
\hline Sector & Netherlands & Zuid-Holland & Flevoland \\
\hline 1. Agriculture, forestry and fishing & 1.69 & 1.34 & 1.36 \\
\hline 2. Extraction of minerals and chemical industry & 1.28 & 1.26 & 1.16 \\
\hline 3. Food, drink and tobacco industry & 1.74 & 1.50 & 1.39 \\
\hline 4. Textile industry & 1.32 & 1.23 & 1.17 \\
\hline 5. Leather, leather goods, footwear and clothing industry & 1.33 & 1.22 & 1.22 \\
\hline 6. Timber and wooden furniture industry & 1.23 & 1.20 & 1.16 \\
\hline 7. Manufacturing of paper and paper products & 1.36 & 1.26 & 1.24 \\
\hline 8. Printing and publishing & 1.52 & 1.37 & 1.26 \\
\hline 9. Manufacturing of products for construction & 1.39 & 1.34 & 1.27 \\
\hline 10. Production and preliminary processing of metals & 1.37 & 1.33 & 1.24 \\
\hline 11. Metal products and machinery & 1.35 & 1.31 & 1.23 \\
\hline 12. Electrical industry & 1.24 & 1.26 & 1.19 \\
\hline 13. Manufacturing of transport products & 1.39 & 1.30 & 1.23 \\
\hline 14. Other industries & 1.38 & 1.29 & 1.25 \\
\hline 15. Energy and water & 1.70 & 1.53 & 1.38 \\
\hline 16. Construction & 1.68 & 1.56 & 1.43 \\
\hline 17. Wholesale and retail distribution & 1.37 & 1.29 & 1.20 \\
\hline 18. Hotels and catering & 1.58 & 1.43 & 1.34 \\
\hline 19. Repair of consumer goods and vehicles & 1.26 & 1.22 & 1.16 \\
\hline 20. Transport & 1.36 & 1.32 & 1.21 \\
\hline 21. Communication & 1.26 & 1.19 & 1.15 \\
\hline 22. Banking and finance & 1.29 & 1.25 & 1.17 \\
\hline 23. Insurance & 1.62 & 1.46 & 1.34 \\
\hline 24. Letting of real estate by the owner & 1.12 & 1.12 & 1.08 \\
\hline 25. Business services and renting & 1.36 & 1.24 & 1.19 \\
\hline 26. Medical, health and veterinary services & 1.18 & 1.16 & 1.11 \\
\hline 27. Culture, sport and recreation & 1.52 & 1.36 & 1.29 \\
\hline 28. Other services & 1.28 & 1.22 & 1.15 \\
\hline 29. Public services & 1.34 & 1.29 & 1.21 \\
\hline Weighted multiplier & 1.41 & 1.31 & 1.25 \\
\hline
\end{tabular}

Table 5

Simple Output Multipliers 
Second, the output multiplier of the agricultural sector (sector 1) in Flevoland (1.36) is higher than the one for Zuid-Holland (1.34). However, our general conclusions are supported by the weighted output multipliers presented at the bottom of Table 5. The weighted output multiplier is computed as the weighted average of all sectoral multipliers within a region

Install Equation Editor and double-

click here to view equation.

Based on this weighted multiplier, we can conclude from Table 5 that a change in final demand will on average increase production by $10 \%$ more in the Netherlands than in Zuid-Holland. The difference between Zuid-Holland and Flevoland is about $6 \%$.

In addition to the comparison between large and small regions, we can also compare the development of output multipliers in different regions. In Figure 3, we present the 1980-1990 development of the simple output multiplier in economically the largest sector in the Netherlands, "Wholesale and retail distribution" (sector 17).

\section{ContainsDatafor \\ PostscriptOnly.}

Figure 3

Simple Output Multipliers

The Netherlands, 1980-1990, 12 Regions, Sector 17

(Wholesale and Retail Distribution) 
The output multiplier of this sector decreased a little in the 1980-1990 period for the Netherlands as a whole, and this decrease can also be found in Friesland, Drenthe, Overijssel, Utrecht, Gelderland and Noord-Brabant. Clear patterns of multiplier increases can be found in Groningen, Zuid-Holland and Zeeland. In the other regions, a clear pattern in the development of the multiplier cannot be discovered.

This concludes our section on output multipliers. We are able to analyze multipliers for every region and every sector seperately throughout the 1980-1992 period, but in this paper we merely want to discuss our ideas and the possibilities of our database.

In the next sections, we will concentrate on employment multipliers and employment transformators.

\section{Employment Multipliers}

Labour market issues have become increasingly important in the formulation of regional economic policy, since striking regional differences exist with respect to regional labour market conditions. Those differences in labour market conditions result in differences in structural unemployment rates between regions (see e.g. Layard et al (1991), chapter 6). Even more than in terms of production 
or income, regional policy makers are interested in employment effects of public investment programs. In this section, we will concentrate on employment multipliers, which can be used for the preparation and evaluation of these investment programs. The employment multiplier describes the total (direct and indirect) employment effect of creating one job in a sector. The employment multiplier is closely related to the output multiplier. The number of workers $N$ per unit of output $X$, which is the inverse of (an approximation of) labour productivity, is used for the definition of the employment multiplier ${ }^{5}$, which is given by

\section{Install Equation Editor and double-}

click here to view equation.

In this section we will discuss the employment multipliers (method 2) in the same way as we discussed the simple output multipliers in the previous section. Therefore, we will first concentrate on differences between large and small regions. In Table 6 (next page), we present the 1992 sectoral employment multipliers for the Netherlands, Zuid-Holland and Flevoland. In general, the conclusions from the previous section can be repeated in this section: national employment multipliers are higher than regional ones, and large regions seem to have higher employment multipliers than small regions. However, there are a few more exceptions on these general conlusions in comparison with the previous section. First, the exceptions mentioned in the previous section are still present in Table 6: Flevoland's multiplier is higher than Zuid-Holland's one in the agricultural sector (1) and Zuid-Holland's multiplier is higher than the national one in the electrical industry (sector 12). In the latter case, however, Flevoland's (employment) multiplier is now higher than Zuid-Holland's one.

\begin{tabular}{|l|c|cc|}
\hline Sector & Netherlands & Zuid-Holland & Flevoland \\
\cline { 2 - 3 } 1. Agriculture, forestry and fishing & 4.70 & 3.80 & $\mathbf{4 . 1 6}$ \\
2. Extraction of minerals and chemical industry & 1.72 & $\mathbf{1 . 8 3}$ & 1.28 \\
3. Food, drink and tobacco industry & 3.08 & 2.92 & 1.84 \\
4. Textile industry & 1.48 & 1.29 & 1.28 \\
5. Leather, leather goods, footwear and clothing industry & 1.39 & 1.27 & 1.22 \\
6. Timber and wooden furniture industry & 1.29 & 1.26 & 1.21 \\
7. Manufacturing of paper and paper products & 1.53 & 1.38 & 1.20 \\
8. Printing and publishing & 1.61 & 1.46 & 1.34 \\
9. Manufacturing of products for construction & 1.51 & 1.43 & $\mathbf{1 . 4 5}$ \\
10. Production and preliminary processing of metals & 1.58 & 1.49 & 1.12
\end{tabular}




\begin{tabular}{|l|l|ll|} 
11. Metal products and machinery & 1.40 & 1.36 & 1.29 \\
12. Electrical industry & 1.32 & $\mathbf{1 . 3 6}$ & $\mathbf{1 . 3 8}$ \\
13. Manufacturing of transport products & 1.56 & 1.39 & 1.34 \\
14. Other industries & 1.43 & 1.34 & $\mathbf{1 . 4 3}$ \\
15. Energy and water & 1.99 & 1.51 & $\mathbf{1 . 7 7}$ \\
16. Construction & 1.86 & 1.74 & 1.63 \\
17. Wholesale and retail distribution & 1.54 & 1.47 & 1.41 \\
18. Hotels and catering & 1.64 & 1.56 & 1.48 \\
19. Repair of consumer goods and vehicles & 1.38 & 1.36 & 1.31 \\
20. Transport & 1.45 & 1.45 & 1.27 \\
21. Communication & 1.27 & 1.20 & 1.18 \\
22. Banking and finance & 1.39 & 1.35 & 1.24 \\
23. Insurance & 1.78 & 1.62 & 1.40 \\
24. Letting of real estate by the owner & 2.35 & 2.12 & 1.71 \\
25. Business services and renting & 1.46 & 1.37 & 1.33 \\
26. Medical, health and veterinary services & 1.19 & 1.19 & 1.17 \\
27. Culture, sport and recreation & 1.60 & 1.43 & 1.38 \\
28. Other services & 1.19 & 1.16 & 1.14 \\
29. Public services & 1.31 & 1.29 & 1.24 \\
Weighted multiplier & $\mathbf{1 . 8 2}$ & $\mathbf{1 . 6 8}$ & $\mathbf{1 . 8 1}$ \\
\hline
\end{tabular}

Table 6

Employment Multipliers

The Netherlands, Zuid-Holland, Flevoland, 1992

Compared with the results of the previous section, Flevoland seems to have better employment possibilities in a few other sectors than Zuid-Holland (sectors 1, 9, 12, 14 and 15). We also should point at the higher than the national employment multiplier in Zuid-Holland in the "Extraction of minerals and chemical industry" (sector 2). Finally it is worthwhile to stress the better employment opportunities of Flevoland (relative to Zuid-Holland) measured by the higher weighted employment multiplier in Table 6. This multiplier is defined in a similar way as the weighted output multiplier (see equation 23).

Flevoland has a slightly lower multiplier than the Netherlands as a whole, whereas the Zuid-Holland multiplier is much lower.

Like in the previous section, we also present a figure which describes the 1980-1990 development of the employment multipliers of the distinguished regions for the economically largest sector of the Netherlands (Figure 4). 


\section{ContainsDatafor}

\section{PostscriptOnly.}

Figure 4

Employment Multipliers

The Netherlands, 1980-1990, 12 Regions, Sector 17

(Wholesale and Retail Distribution)

This figure ressembles Figure 3 in the sense that regional multipliers are also lower than the national 
one. The decrease in the national output multiplier in this sector caused the national employment multiplier also to decrease in the 1980-1990 period. However, the 1985-1990 decrease in the national employment multiplier seems to be more severe than the 1985-1990 decrease in the output multiplier (see Figure 3). This development can be explained in two ways: either the cost of creating an extra job in this sector decreased too, or the employment effect of additional final demand decreased in the same period. The latter explanation refers to an increase in labour productivity, possibly caused by technological improvements.

In the following section, we concentrate on employment transformators.

\section{Employment Transformators}

Public investment programs could aim at the creation of employment, but are never specified in terms of jobs to be created. They are rather put in monetary terms (millions of dollars or guilders). In this section, we present employment transformators which describe the total (direct and indirect) employment effect of a change in (public) spending. The employment transformator is closely related to both the output multiplier and the employment multiplier, and is defined as

Comparing the equations (24) and (25), it is obvious that the employment transformator describes the same employment effect as the employment multiplier, without relating the employment effect to the employment/output ratio of the sector under investigation. In Table 7, we present the 1992 total and direct employment effect of additional final demand for the 12 Dutch regions.

\begin{tabular}{|l|r|r|r|}
\hline \multirow{2}{*}{} & \multicolumn{3}{|c|}{$\begin{array}{c}\text { Employment Effect } \\
\text { (full time jobs) }\end{array}$} \\
\cline { 2 - 4 } & Total & Direct & $\%$ \\
\hline Netherlands & $\mathbf{7 . 2}$ & $\mathbf{5 . 7}$ & $\mathbf{7 9 . 7}$ \\
Groningen & 4.9 & 4.3 & 88.0 \\
Friesland & 6.3 & 5.4 & 85.7 \\
Drenthe & 6.3 & 5.5 & 87.0 \\
Overijssel & 6.4 & 5.6 & 87.5 \\
Flevoland & 7.4 & 6.5 & 87.6 \\
Noord-Holland & 7.1 & 6.0 & 83.4 \\
Zuid-Holland & 6.7 & 5.5 & 83.3 \\
Utrecht & 7.7 & 6.5 & 83.7 \\
Gelderland & 6.7 & 5.8 & 86.0 \\
Noord-Brabant & 6.4 & 5.5 & 85.5 \\
Zeeland & 5.3 & 4.5 & 84.6 \\
Limburg & 6.5 & 5.6 & 86.0 \\
\hline
\end{tabular}




\section{Table 7}

Total and Direct Employment Effect

The Netherlands, 1992, 12 Regions

Utrecht has a higher employment transformator than the Netherlands as a whole, and 3 more regions (Flevoland, Noord-Holland and Gelderland) also have a higher direct employment effect.

The employment effects of the other regions are lower than the national effect. The relative direct employment effect of additional final output is smaller for the Netherlands as a whole than for the regions (last column). At the national level, more than $20 \%$ of the total employment effect is due to the indirect effect, whereas at the regional level this percentage ranges between 12 (Groningen) and almost 17 (Zuid-Holland).

In Figure 5, we present the 1980-1990 employment transformators for the wholesale and retail distribution sector (17), as we did in the previous two sections.

\section{ContainsDatafor}

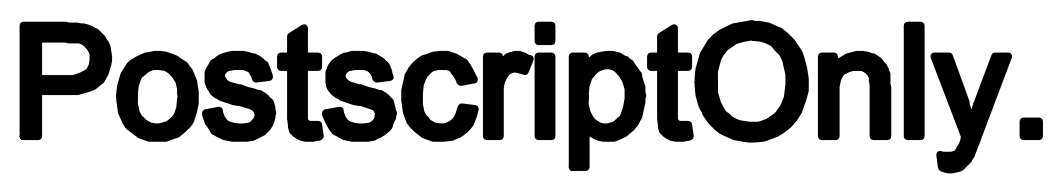

Figure 5

Employment Transformators

The Netherlands, 1980-1990, 12 Regions, Sector 17

(Wholesale and Retail Distribution) 
In the 1980-1990, the development of transformators was identical for all regions. In this sector, the national employment transformator was always higher than the regional ones. The absolute value of the national transformator dropped from almost 15 (full time jobs) down to just over 11 . The decrease of the regional transformators was equally dramatic. This development, which is obviously more due to the decrease in the number of workers per output unit than in the output multiplier (see Figure 3), is consistent with an increase in labour productivity, possibly caused by technological innovations.

For the wholesale and retail distribution sector, this explanation seems to be plausible when the effects of the introduction of information technology and computers is considered.

This completes our discussion of the employment transformators. In the last section, we will summarize and elaborate on policy applications of the proposed input-output framework.

\section{Summary and Policy Recommendations}

In this paper, we defined regional input-output tables in order to analyze regional economic structures. We started by describing the availability of regional data in the Netherlands. The regional dataset already fills part of the regional IO tables that we are after. However, no information is available about regional intermediary transactions and trade flows, except for regional (international) exports. Therefore, we defined international imports at the regional level on the basis of the national ratio between imports and total inputs. Interregional trade flows were 
based on interregional transport characteristics. Total imports and exports range between 20 and 30 percent of total input or output.

In addition to one existing technique for computing regional intermediary transactions, proposed by Klaassen and Verster (1974), we developed a second methodoloy (symmetric adjustment). Instead of an asymmetric treatment of sectoral specialization at the regional level by truncating cross-sectoral location quotients, as proposed by Klaassen and Verster (1974), we develop a symmetric adjustment index by which sectoral specialization is taken care of in a more satisfying way. On the basis of the definitions of intermediary transactions in both methods, the Klaassen and Verster (1974) intermediary transactions would underestimate total regional intermediary transactions. However, by definition of our input-output framework, as explained in section 4 , the sectoral totals of intermediary transactions are already fixed before we compute these transactions. Therefore, the computed intermediary transactions are rescaled to the prefixed totals, which means that a comparison between the two techniques is not very instructive. However, the results differ, as was discussed in section 6.

Simple output multipliers, employment multipliers and employment transformators were discussed throughout the sections 7, 8 and 9. National economic indicators are on average higher than regional indicators, pointing at the presence of more economic leakages at the regional level (interregional imports). Indirect employment effects of economic policy are bigger at the national than at the regional level.

Some of the assumptions made in this paper, for the purpose of constructing the regional IO tables, call for policy actions. On the other hand, the richness of the IO system discussed in this paper should be stressed again. Much of the (theoretical) material presented in this paper can serve as a starting point for a complete regional information system. At the end of this paper, we present some policy recommendations with respect to both constructing and using the regional IO system.

- More information must become available about interregional trade flows, because the derivation of them in the current IO system is not satisfactory. Intuitively, we expect the level of interregional trade to be higher than reported in Table 3 of this paper, but we have no data available to support this statement.

- Regional IO systems can serve as a basis for the development of a regional economic information system, at every policy level (regional, national and international). Such a system cannot only cover the links between business sectors and between regions, but it also provides opportunities 
to expand the system with (additional) regional information.

- Regional multipliers and transformators can be used in the preparation and the evaluation of public investment programs. They provide useful insight in the economic consequences of public economic policy.

- Regional databases of firms and establishments should be used as informational references in order to backup regional IO systems. These databases should become available and must be combined with (aggregated) IO information. The level of aggregation ensures the secrecy of firm specific, sensitive information. 


\section{Notes}

hroughout the paper we will use the following abbreviations for the regions (from the north to the south): GR=Gronin: :Friesland, $\quad \mathrm{DR}=$ Drenthe, $\quad \mathrm{OV}=$ Overijssel, $\quad \mathrm{FL}=$ Flevoland, $\quad \mathrm{NH}=$ Noord-Holland, $\mathrm{ZH}=$ Zuid-Holland, UT=Utre $=$ Gelderland, NB=Noord-Brabant, $\mathrm{ZE}=$ Zeeland, LI=Limburg. Sometimes, we refer to the Netherlands with the eviation.

Ve only have data available at the aggregated level of 4 regions. The correspondence between our regional classification e 4 regions is as follows: NORTH=Groningen, Friesland and Drenthe, EAST=Overijssel, Flevoland and Gelderli ST=Noord-Holland, Zuid-Holland, Utrecht and Zeeland, SOUTH=Noord-Brabant and Limburg.

slaassen and Verster (1974) define the cross-sectoral location quotient in terms of employment. In the construction of onal IO tables, however, we prefer to define the quotient in terms of output. We think that output is a better indicator rmediary transactions than the level of employment.

he output multipliers are calculated on the basis of method 2 (symmetric adjustment index).

ee Miller and Blair (1985), chapter 4, for a complete description of the employment multiplier. 


\section{References}

Klaassen, L.H. and A.C.P. Verster (1974), Kosten-baten analyse in regionaal perspectief, Groningen.

Layard, R., Nickell, S. and R. Jackman (1991), Unemployment. Macroeconomic Performance and the Labour Market, Oxford University Press, New York.

Miller, R.E. and P.D. Blair (1985), Input-Ouput Analysis. Foundations and Extensions, PrenticeHall, Englewood Cliffs. 


\begin{tabular}{|c|c|}
\hline Sector Description & $\begin{array}{l}\text { NACE Rev.1 } \\
\text { Code }\end{array}$ \\
\hline 1. Agriculture, forestry and fishing & 01-05 \\
\hline 2. Extraction of minerals and chemical industry & $10-14,23-26$ \\
\hline 3. Food, drink and tobacco industry & $15-16$ \\
\hline 4. Textile industry & $17-18$ \\
\hline 5. Leather, leather goods, footwear and clothing industry & 19 \\
\hline 6. Timber and wooden furniture industry & 20,36 \\
\hline 7. Manufacturing of paper and paper products & 21 \\
\hline 8. Printing and publishing & 22 \\
\hline 9. Manufacturing of products for construction & 20 \\
\hline 10. Production and preliminary processing of metals & 27 \\
\hline 11. Metal products and machinery & $28-29$ \\
\hline 12. Electrical industry & $30-33$ \\
\hline 13. Manufacturing of transport products & $34-35$ \\
\hline 14. Other industries & $36-37$ \\
\hline 15. Energy and water & $40-41$ \\
\hline 16. Construction & 45 \\
\hline 17. Wholesale and retail distribution & 51 \\
\hline 18. Hotels and catering & 55 \\
\hline 19. Repair of consumer goods and vehicles & 50,52 \\
\hline 20. Transport & $60-63$ \\
\hline 21. Communication & 64 \\
\hline 22. Banking and finance & 65,67 \\
\hline 23. Insurance & 66 \\
\hline 24. Letting of real estate by the owner & 70 \\
\hline 25. Business services and renting & $71-74$ \\
\hline 26. Medical, health and veterinary services & 85 \\
\hline 27. Culture, sport and recreation & $90-93$ \\
\hline 28. Other services & 95 \\
\hline 29. Public services & 75,80 \\
\hline
\end{tabular}

